\title{
Mentalizacja jako czynnik ochronny pomiędzy pozabezpiecznym przywiązaniem a rozwojem zaburzeń psychopatologicznych
}

\section{Mentalization as a Protective Factor between Insecure Attachment and the Development of Psychopathological Disorders}

\begin{abstract}
The development of mental disorders in adults has its roots in the early childhood experiences. Transmitted from generation to generation, an insecure attachment impairs the ability to mentalize, which plays a special role in the processing of traumatic injuries and the healing process. The aim of the article is to show the development of mental disorders in children and adults; to present mentalization as a protective factor in the transmission of insecure attachment, as well as to indicate clinical implications.
\end{abstract}

Keywords: mentalization, insecure attachment, trauma of attachment, intergenerational transmission

Słowa kluczowe: mentalizacja, pozabezpieczne przywiązanie, trauma więzi, transmisja międzypokoleniowa

\section{TWORZENIE SIĘ PRZYWIĄZANIA}

Bliskie związki są istotnym elementem życia każdego człowieka. John Bowlby (1973) zauważył, że potrzebę tworzenia więzi z drugim człowiekiem widać na każdym etapie życia, ale relacja przywiązaniowa ma szczególne znaczenie w okresie wczesnodziecięcym, kiedy biologiczną koniecznością jest wytworzenie więzi dziecka z głównym opiekunem. Potrzeba ta opiera się na emocjonalnej relacji oraz stanie fizycznym i psychicznym, który udaje się osiągnąć dzięki bliskości i responsywności figury przywiązania. Istotną rolę w teorii więzi odgrywają wewnętrzne modele operacyjne (WMO). Za ich centralny aspekt uznaje się wiedzę na temat głównego opiekuna oraz jego dostępności i zdolności reagowania. WMO gromadzą wiedzę na temat własnej osoby i głównego opiekuna oraz przechowują ją w strukturach pamięci. Wiedza ta jest generowana na podstawie doświadczeń interakcji w bliskiej relacji. WMO pozwalaja dziecku przewidywać zachowania występujące w relacji. Zakłada się, że ta „baza wiedzy” wynikająca z więzi stanowi źródło pewnego stopnia ciągłości doświadczenia i zachowania w bliskich relacjach interpersonalnych (Daniel, 2009). Obecnie badacze definiują WMO jako hierarchicznie zorganizowane sieci reprezentacji, w tym wspomnienia o konkretnych wydarzeniach związanych z relacją przywiązaniowa, a także specyficzne dla relacji i ogólne oczekiwania dotyczące przywiązania oraz postawy i strategie działania (Mikulincer, Shaver, 2007). Właśnie w tej pierwszej bliskiej relacji, zazwyczaj z matką, u dziecka rozwijają się przeko- 
nania odnośnie do wiarygodności innych osób oraz oczekiwania co do ich zachowań, a także przekonanie, czy jednostka jest godna uwagi i zasługuje na otrzymywanie opieki. Tworzą się skrypty, które są reprezentacją siebie i innych. Stają się one stabilnymi, trudnymi do zmiany składnikami osobowości, a w konsekwencji wpływają na tworzone w przyszłości relacje z innymi ludźmi (Fricker, Moore, 2002).

Liczne badania wykazały, że dzieci, których opiekunowie wykazywali responsywność na ich potrzeby, w WMO mają pozytywny obraz siebie i innych. W konsekwencji są bardziej empatyczne, dominują u nich pozytywne emocje, łatwiej regulują i komunikują emocje, wykazują większą bezpośredniość i stosunkowo łatwo nawiązują relacje rówieśnicze (Iniewicz, 2008). Względna stałość wzorców przywiązania w pespektywie czasowej pokazuje, że dorośli, którzy w dzieciństwie mieli warunki do stworzenia bezpiecznej więzi z opiekunem, osiągają większą satysfakcję z relacji partnerskiej, budują bardziej trwałe, ufne związki w dorosłości (Mikulincer, Shaver, 2007). Bezpieczne przywiązanie u dorosłych wiąże się także z zaspokajaniem potrzeb autonomii, bliskości i kompetencji (La Guardia i in., 2000), umiejętnością efektywnego radzenia sobie $\mathrm{z}$ trudnymi emocjami oraz niskim wskaźnikiem negatywnego afektu (Mikulincer, Shaver, 2007).

\section{POZABEZPIECZNE PRZYWIĄZANIE}

\section{Jako traumatyczne wczesnodziecięce doświadczenie}

Gdy fizyczne i emocjonalne potrzeby dziecka nie były zaspokajane, a opiekun nie wykazywał responsywności, prawdopodobnie została wytworzona jedna $\mathrm{z}$ pozabezpiecznych więzi: lękowo-unikająca, lękowo-ambiwalentna lub zdezorganizowana. Chociaż wewnętrzne modele operacyjne w każdym $\mathrm{z}$ tych wzorców się różnią, to ich wspólnym mianownikiem pozostaje brak poczucia bezpieczeństwa. Inni postrzegani sąjako nie zawsze reagujący na potrzeby dziecka, niedostępni emocjonalnie i fizycznie lub zagrażający (Senator, 2010). Te fizyczne i psychiczne zaniedbania ze strony opiekuna w okresie wczesnodziecięcym mogą przybierać charakter traumatyczny. Szczególnym rodzajem takiego doświadczenia jest trauma więzi, która charakteryzuje przede wszystkim przywiązanie zdezorganizowane. Wiąże się ona ściśle $z$ traumatycznym rozwojem i bywa również nazywana urazem przywiązaniowym. Odnosi się do różnych rodzajów stresujących wydarzeń, które powtarzają się wielokrotnie. Zwykle kumulują się w pewnym okresie i dotyczą konkretnej relacji - przeważnie z głównym opiekunem (Farina i in., 2019). Na podstawie National Centre of Excellence for Complex Trauma autorzy Deborah J. Oelhman Forbes, Megan Lee i Richard Lakeman (2020) definiują traumę interpersonalną w następujących kategoriach: a) trauma spowodowana czymś, co zrobiono dziecku; b) uraz spowodowany czymś, co się nie wydarza - zaniedbania podstawowych fizycznych i emocjonalnych potrzeb dziecka; c) trauma spowodowana tym, że opiekun dziecka sam jest dotknięty własnym urazem, na przykład konfliktem okołorozwodowym, chorobą psychiczną najbliższych, nadużywaniem substancji psychoaktywnych lub alkoholu.

Badacze Giovanni Liotti i Benedetto Farina (2019) postawili hipotezę, wedle której w przywiązaniu zdezorganizowanym oba komplementarne elementy WMO (model siebie i model innych) mogą nie być spójne, ale różne i niezintegrowane ze sobą. WMO zdezorganizowany może być wewnętrznie zdysocjowany pod względem treści reprezentacji siebie. Dzieje się tak w sytuacji długotrwałego doświadczania stresu i bezsilności przez dziecko. Aktywuje to przewlekłą reakcję neurobiologiczną, która zakłóca prawidłowy rozwój mózgu (De Bellis, Zisk, 2014; Teicher i in., 2016). Jednoczesne tendencje do zbliżania się i ucieczki w kontakcie z przemocowym opiekunem nie mogą być przyswojone przez dziecko w tych samych ramach znaczeniowych, a więc nie zostają zintegrowane w jeden akt syntezy umysłowej. Ponadto równoczesna, sprzeczna potrzeba aktywacji systemów obrony przywiązania i przetrwania wyzwala autonomiczną reakcję przywspółczulnego odłączenia (Liotti, Farina, 2016). Może to trwale 
utrudniać zdolność integracyjną, powodując objawy segmentacji i strukturalną dysocjację osobowości, a także wspomnień autobiograficznych. Skutkiem tego może być powstanie kilku sprzecznych i wzajemnie zdysocjowanych reprezentacji ,ja”.

\section{Jako patomechanizm powstawania zaburzeń psychicznych}

W trakcie badań nad teorią przywiązania zebrano wiele dowodów wskazujących na to, że relacja z figurą przywiązania może zmieniać struktury neuroanatomiczne zaangażowane w funkcjonowanie systemu przywiązania, a przez to wpływać na rozwój umiejętności emocjonalnych, poznawczych i metapoznawczych (Farina, Liotti, 2013). Według Allana N. Schore'a (2001) wytworzenie więzi zależy od psychobiologicznych uwarunkowań dziecka, wspomnianych już doświadczeń z rodzicem oraz mechanizmów przywiązania. Traumatyczne doświadczenia nie pozostają bez wpływu na mózg i jego funkcjonowanie. Umiejscowiony w prawej półkuli układ limbiczny rozwija się szczególnie intensywnie w ciągu pierwszych dwóch lat. Pełni szczególną funkcję w procesach społeczno-emocjonalnych oraz sposobie doświadczania. Oznacza to, że nadużycia traumatyczne w tym okresie życia dziecka zmieniają rozwój prawej półkuli mózgu. Jeżeli dziecku brakuje wsparcia w procesie regulacji emocji oraz obniżania poziomu napięcia, to połączenia w obszarze układu limbicznego są narażone na działanie neurotransmiterów, takich jak kortyzol czy glutaminian. W dłuższym czasie mają one toksyczny wpływ na rozwój i funkcjonowanie mózgu. Co więcej, kora prawej półkuli odgrywa dominującą rolę w procesie powstawania więzi z opiekunem i wewnętrznych modeli operacyjnych dziecka. Bessel van der Kolk (van der Kolk i in., 1996) twierdzi, że w wyniku stresu doświadczanego w bliskiej relacji z opiekunem u dziecka mogą się rozwinąć zaburzenia funkcjonowania układu hipokamp-ciało migdałowate. Dochodzi wówczas do zwiększonego wydzielania neurohormonów oraz nadmiernej stymulacji ciała migdałowatego, a to może upośledzać funkcjonowanie hipo- kampu. Rezultatem może być obniżona zdolność kategoryzacji i zapamiętywania u dziecka. Znaczenie i ocena poznawcza doświadczenia mogą zostać zahamowane. Tezę tę wspierają Eun Joo Kim, Blake Pellman i Jeansok J. Kim (2015), twierdząc, że funkcjonowanie hipokampa może ulec zaburzeniu w wyniku silnego stresu. W niektórych przypadkach następuje jego kurczenie się. Zmniejszenie hipokampu wpływa na wzmożone odczuwanie negatywnych doświadczeń: osoby, których hipokamp jest mniejszy, oceniają swoje doświadczenia jako bardziej stresujące (Lindgren i in., 2016). Traumatyczne doświadczenia powodują spadek aktywacji ośrodka Broki, co w znacznym stopniu zubaża narrację. Ponieważ werbalizacja traumatycznych przeżyć wpływa na obniżenie liczby psychosomatycznych objawów, to brak możliwości ich wyrażania w sposób symboliczny - po pierwsze - nasila symptomy, a po drugie - utrudnia sprawowanie kontroli nad impulsami. Oznacza to, że w przypadku doświadczania zaniedbań i traumy we wczesnych latach dzieciństwa może powstać jedna z pozabezpiecznych więzi, co w znacznym stopniu utrudnia symboliczną reprezentację własnych stanów wewnętrznych i powoduje przechodzenie od impulsu do reakcji, czyli gwałtowne reagowanie na stres (Słaboń-Duda, 2011). Osoby, których potrzeba bezpieczeństwa w dzieciństwie nie została zaspokojona właściwie, w późniejszych okresach rozwojowych moga mieć trudności w kontrolowaniu swoich reakcji emocjonalnych. Badania pokazują, że negatywny wpływ traumatycznych doświadczeń we wczesnym dzieciństwie może się odbijać na funkcjach psychicznych, które w największym stopniu są zależne od rozwoju i funkcjonowania dużych sieci asocjacyjnych lub integracji różnych obszarów mózgu (takich jak kontrola emocjonalna i pamięć autobiograficzna) (Farina, Liotti, 2013). Wielokrotne zdysocjowane reprezentacje siebie i figury przywiązania u niemowląt w zdezorganizowanym wzorcu więzi są czynnikami ryzyka upośledzonego rozwoju zdolności integracji wspomnień afektywnych i regulacji emocjonalnej (Liotti, Farina, 2016), a więc wczesna, przywiązaniowa relacja między opiekunem a dzieckiem warunkuje rozwój 
regulacji emocji u dzieci. Według Mario Mikulincera i Phillipa R. Shavera (2008) dzieje się to na poziomie struktury intrapsychicznej, opisującej związek między wewnętrzną reprezentacją więzi (WMO) a strategiami regulacji emocji. Jest to rodzaj regulatora emocjonalnego funkcjonowania jednostki, który później staje się szablonem dla przyszłych strategii regulacji emocji. Oznacza to, że doświadczenia wynikające z relacji przywiązaniowych wpływają na funkcjonowanie człowieka przez regulację emocji. Dotyczy to także dorosłości (Marszał, Jańczak, 2017).

Metaanaliza przeprowadzona przez R.M. Pasco Fearona i Glenna I. Roismana (2017) potwierdza tezę, że u dzieci bezpieczne przywiązanie wiąże się z lepszymi wynikami społeczno-emocjonalnymi. Wspomniana metaanaliza dostarcza wskazówek co do zakresu i ograniczeń potencjalnego wpływu przywiązania na rozwój społeczno-emocjonalny. Podobne wnioski przedstawiają Ashley M. Groh $\mathrm{i}$ in. (2016): wczesnodziecięce doświadczenia „bezpiecznej bazy” wiązały się z większymi kompetencjami społecznymi, mniejszą liczbą problemów eksternalizacyjnych oraz z mniejszą liczbą problemów internalizacyjnych. Związek między przywiązaniem a problemami eksternalizacyjnymi narastał $\mathrm{z}$ wiekiem. Autorzy przedstawiają dowody na to, że bezpieczne przywiązanie jest silniej skorelowane z późniejszymi kompetencjami społecznymi i eksternalizacją niż z internalizacją. Badacze podkreślają, że wyniki te mogą być zaskakujące w świetle przypuszczalnego znaczenia przywiązania w regulowaniu uczucia niepokoju lub strachu u dzieci. Wysnuli oni hipotezę WMO, według której relacje społeczne moga być najściślej związane z przywiązaniem, jeśli założyć, że eksternalizacja problemów w dzieciństwie odzwierciedla trudności w relacjach z rówieśnikami (Fearon, Roisman, 2017). Wyniki metaanalizy Groh i in. (2016) wykazały, że wszystkie rodzaje pozabezpiecznych wzorców więzi łączą się z obniżonymi kompetencjami społecznymi. Przywiązanie unikowe może implikować zaburzenia eksternalizacyjne i internalizacje, natomiast dezorganizowane przywiązanie ma znaczenie w etiologii zabu- rzeń eksternalizacyjnych. Dzieci, które mają pozabezpieczny wzorzec więzi, mogą wykazywać wyższy poziom stresu, obniżone stężenie czynników odpornościowych (Hertsgaard i in., 1995), mniejszą pewność siebie, większą bierność i wycofanie. Mogą okazywać więcej negatywnych uczuć i agresji, a w konsekwencji otoczenie może odbierać je jako złośliwe. Zachowania internalizacyjne obejmują objawy związane z depresją i lękiem, a także izolacją społeczną i wycofaniem (Madigan i in., 2013).

\section{Jako predyktor rozwoju zaburzeń psychopatologicznych w dorosłości}

Wczesne traumatyczne doświadczenia w relacji przywiązaniowej mają wiele negatywnych skutków rozwojowych oraz wpływają na powtórzenie wzorca $\mathrm{w}$ relacjach interpersonalnych. Zaniedbania w obszarze rozwoju więzi prowadzą również do zaburzeń psychicznych w dorosłości. Stany emocjonalne i osobiste znaczenia, oddzielone od wspomnień związanych z wydarzeniami, które je wywołuja, moga w wieku dorosłym wywoływać nagłe, intensywne emocje, niekontrolowane fobie i ataki lęku, nieuzasadnione napady złości, dramatyczne i wrogie interpretacje (Farina, Liotti, 2013). Według większości współczesnych badaczy utrata integracji spowodowana stanem dysocjacyjnym obejmuje także: osłabioną kontrolę afektu i impulsów, potraumatyczne odrętwienie emocjonalne, obniżoną zdolność do refleksji nad własnymi stanami psychicznymi i stanami psychicznymi innych oraz utratę spójności obrazu siebie i narracji autobiograficznej (Farina, Liotti, 2013). W licznych badaniach wykazano związki między pozabezpiecznym przywiązaniem a PTSD (Ein-Dor i in., 2010), depresją (Wei i in., 2004), zaburzeniami odżywiania (Illing, 2010), zespołem lęku uogólnionego (GAD), fobią społeczną i atakami paniki (Krueger, Markon, 2011). Obecnie uznaje się również, że zaburzenia osobowości typu borderline, narcystyczne i antyspołeczne mogą być pochodną traumatycznych doświadczeń wczesnodziecięcych oraz cech temperamentalnych (Fonagy, Luyten 2009; Mikulincer, Florian, 2003), co może się wiązać z deficytem umie- 
jętności radzenia sobie z pobudzeniem, stresem i regulacją emocji (Migda, 2015).

Liczne badania wykazują związki między pozabezpiecznymi wzorcami więzi a psychopatologia, ale nie podają bezpośredniej przyczyny rozwoju konkretnego zaburzenia. Według Benedetta Fariny i Giovanniego Liottiego (2013) obecność objawów dysocjacyjnych można uznać za wymiar psychopatologiczny wpływający na wszystkie zaburzenia psychiatryczne, które charakteryzują grupy pacjentów z historią rozwoju traumatycznego. Próbę wyjaśnienia, dlaczego mając dany styl przywiązania, ludzie rozwijają różne symptomy zaburzeń, podjęto w transdiagnostycznym modelu przywiązania i psychopatologii zaproponowanym przez Tsachi Eina-Dora, Diny Viglin i Guya Dorona (2016). Zgodnie z nim lękowe przywiązanie może zwiększać podatność na psychopatologię przez czarną triadę: 1) nieprawidłową regulację emocji z tendencją do zwiększonej negatywnej afektywności; 2) większą czujność, przypuszczane zagrożenie; 3 ) postrzeganie innych jako mniej wspierających i w mniejszym stopniu rozumiejących potrzeby. Według Eina-Dora, Viglin i Guya Dorona (2016) powyższe tendencje mogą być czynnikami inicjującymi drugą czarną triadę procesów, które łączą unikającą więź z zaburzeniami psychopatologicznymi: 1) niedostosowane procesy regulacji emocji z tendencją do obniżania poziomu uczuciowości i stosowania strategii dystansowania; 2) przymusową samodzielność; 3) obniżony poziom wsparcia społecznego i postrzeganej wrażliwości innych. Unikanie poznawcze i emocjonalne, kompulsywna samodzielność oraz postrzeganie innych jako nieresponsywnych mogą obejmować transdiagnostyczne czynniki ryzyka, pośredniczące między unikającym stylem więzi a rozwojem psychopatologii. Autorzy w dalszym ciagu zostawiaja bez ostatecznej odpowiedzi pytania: ,Jakie są mechanizmy pośredniczące między skłonnością do przywiązania a zaburzeniami psychicznymi?” oraz „Dlaczego dana skłonność rozwija różne zaburzenia u różnych osób lub $\mathrm{z}$ biegiem czasu prowadzi do odmiennych zaburzeń u tej samej osoby?". Bardziej kompleksowe spojrzenie na trajektorię rozwojową łączącą wczes- ne wpływy środowiskowe z psychopatologia dorosłych przedstawił Peter Fonagy. Według niego zmienną pośredniczącą między traumatycznymi doświadczeniami z dzieciństwa, cechami temperamentu a rozwojem zaburzeń psychicznych jest brak zdolności do ich opracowania. Wiąże się to z zaburzeniem mentalizowania (Marszał, 2015).

\section{MENTALIZOWANIE JAKO ZDOLNOŚĆ DO PRZEPRACOWYWANIA TRAUMATYCZNYCH DOŚWIADCZEŃ}

Mentalizacja jest aktywnością wyobrażeniową umysłu, która umożliwia spostrzeżenie, uświadomienie sobie i interpretowanie zachowań innych ludzi w kategoriach intencjonalnych stanów umysłu. Odgrywa znaczącą rolę w codziennym życiu i poprawia jego komfort, ponieważ umożliwia rozumienie tworzenia interakcji międzyludzkich oraz zdarzeń społecznych (Adamczyk, 2013). Mentalizacja jest konstruktem wielowymiarowym, dlatego też różne zaburzenia psychopatologiczne stanowią pochodną deficytów na różnych dymensjach. Wyróżniamy kilka rodzajów mentalizacji.

1) Mentalizacje automatyczna (utajona) i jawna (kontrolowana) są procesami ściśle ze sobą powiązanymi i mogą być stosowane w jednym czasie. Mentalizowanie automatyczne przebiega nieświadomie i nierefleksyjnie, a reprezentacje umysłowe w tym trybie powstają na podstawie wcześniejszych doświadczeń $i$ automatycznie warunkują dalszy proces przetwarzania informacji. Pierwszym przejawem niejawnego mentalizowania jest niewerbalne odzwierciedlenie stanów mentalnych innych. Można je obserwować w okolicach drugiego roku życia dziecka. Procesy mentalizacji utajonej w mózgu są związane między innymi z obszarem ciała migdałowatego, a więc podobnie jak w wypadku wczesnych traumatycznych doświadczeń. Mentalizacja jawna jest procesem świadomym, refleksyjnym i ściśle związanym z funkcjonowaniem werbalnym. Uruchamia obszary mózgu odpowiedzialne za przetwarzanie informacji językowych i symbolicznych: boczną korę przedczołową, przyśrodkową korę 
przedczołowa, płat ciemieniowy, przyśrodkową i boczną korę ciemieniową oraz przednią korę zakrętu obręczy (Allen i in., 2014). W znacznym stopniu angażuje procesy uwagowe. W sytuacji stresu i wysokiego pobudzenia jest hamowana, a zależność tę widać szczególnie w sytuacji stresu związanego z przywiązaniem.

2) Mentalizacje poznawcza i afektywna w optymalnej sytuacji powinny działać w sposób zintegrowany. Mentalizacja w aspekcie poznawczym (definiowana czasami jako teoria umysłu) jest zdolnością do tworzenia reprezentacji stanów poznawczych własnych i cudzych, myślenia w kategoriach przekonań oraz wnioskowania o istnieniu nieobserwowalnych stanów mentalnych (przekonań i pragnień), w oparciu o które można przewidywać i rozumieć zachowania społeczne innych ludzi. Mentalizacja afektywna wiąże się z kolei ze zdolnością do rozpoznawania, rozumienia i wnioskowania odnośnie do stanów emocjonalnych. Jest więc systemem empatycznym.

3) Mentalizacja zorientowana na self $i$ mentalizacja zorientowana na obiekt to wnioskowanie o istnieniu własnych i cudzych stanów mentalnych (Marszał, 2015).

Mary Ainsworth (Ainsworth i in., 1978) na podstawie obserwacji dokonanych w Procedurze Nieznanej Sytuacji zauważyła różne reakcje dzieci na sytuację stresującą, jaką jest oddalanie się rodzica. Rozwinęła pierwotną koncepcję Bowlby'ego, stwierdzając, że opisany biologicznie uwarunkowany system przywiązania wykazuje elastyczność, co oznacza, że zachowania opiekuna w znacznym stopniu wpływają na jakość przywiązania, jakie wytworzy dziecko. Jennifer M. Turner, Anja Wittkowski i Dougal Julian Hare (2008) za podłoże do tworzenia się zdolności do mentalizowania uznają prawidłowe odzwierciedlanie przez opiekuna wewnętrznych stanów emocjonalnych dziecka. Procesy interpersonalne, takie jak odzwierciedlanie i rozumienie stanów mentalnych dziecka przez figurę przywiązania, stopniowo przekształcają się w procesy intrapsychiczne, które charakteryzują się między innymi zdolnością do regulowania emocji i mentalizowania (Allen i in., 2014). Wskazuje to jasno na kluczową rolę opiekuna w procesie kształtowania mentalizacji, ale jed- nocześnie na mentalizację jako główny czynnik w międzypokoleniowej transmisji wzorca więzi. Badania wykazują, że zdolność dziecka do mentalizacji zależy od tego, w jaki sposób było ono mentalizowane przez głównego opiekuna (Meins i in., 2001; Slade i in., 2005).

\section{Trudności w rozwoju zdolności do mentalizacji}

Jak wynika z powyższego, mentalizowanie i przywiązanie ściśle się ze sobą łączą. Choć wydaje się, że mentalizujący rodzic odgrywa główną rolę w rozwoju bezpiecznej więzi i mentalizowania u dziecka, to teoretycy przywiązania przyznają, że nie jest to wyłącznie wynik zachowania rodziców. Zdolność opiekuna do angażowania się we właściwe mentalizowanie może być zakłócana przez cechy dziecka, w szczególności związane z temperamentem (Sharp, Fonagy, 2008). Zaburzenie procesu rozwoju mentalizowania może też wystąpić w przypadku całościowego zaburzenia rozwoju. Autyzm związany jest ze względnie stałym brakiem świadomości sfery psychicznej. Dzieci nim dotknięte mają trudności w przypisywaniu innym fałszywych przekonań. W konsekwencji nie rozumieją, że ich przekonania mogą się różnić od przekonań innych ludzi, i dlatego nie są w stanie przewidywać zachowań tych osób, opierając się na obserwacji ich stanów psychicznych (Adamczyk, 2013). Podobne trudności mogą mieć osoby z zaburzeniami depresyjnymi.

\section{Transmisja międzypokoleniowa więzi i mentalizowania}

Analizując więzi tworzone przez dziecko i głównego opiekuna, John Bowlby (1988) zauważył, że bezpieczne przywiązanie jest transmitowane międzypokoleniowo. Jednym z mechanizmów odpowiedzialnych za przekaz wzorca więzi jest obserwacja tego, w jaki sposób opiekun radzi sobie z własnymi emocjami. Według badacza emocje są bardzo ważną składową systemu przywiązania. Są skutkiem działania wewnętrznych modeli operacyjnych i podstawowym czynnikiem organizacji doświadczeń jednostki. Wpływa to na tworzenie strategii regulacji emocji, 
czyli pewnego wzorca sposobu radzenia sobie z obniżaniem negatywnych stanów emocjonalnych i maksymalizacją pozytywnych. Badania wykazuja, że osoby, które w dzieciństwie pozostawały w pozabezpiecznej relacji z opiekunem głównym, mają trudności w zakresie regulacji emocji. Jednocześnie stresujące wydarzenia opisują jako bardziej zagrażające niż osoby przywiązane bezpiecznie (Mikulincer, Florian, 2003). Warto zauważyć, że wspomniane już wcześniej deficyty w regulacji emocji jako czynnik rozwoju psychopatologii (na przykład zaburzenia osobowości borderline) identyfikują także Ein-Dor, Viglin i Doron (2016) w transdiagnostycznym modelu przywiązania i psychopatologii. Według Johna G. Allena, Petera Fonagy’ego i Anthony'ego W. Batemana (2014) klimat bezpiecznego przywiązania tworzy warunki sprzyjające rozwojowi zdolności mentalizowania przez trzy mechanizmy: utrzymywane na niskim poziomie pobudzenie emocjonalne, sprzyjanie procesom eksploracji sfery psychicznej oraz zdolność do mentalizacji, jaką cechuje się główny opiekun. Oznacza to, że mentalizacja odgrywa główną rolę w procesie, w którym bezpieczne przywiązanie jest transmitowane międzypokoleniowo (Sharp, Fonagy, 2008).

W kontekście teorii przywiązania mentalizacja służy dwóm celom. Wczesne doświadczenia dziecka w relacji z opiekunem są ważne dla późniejszej wiedzy metapoznawczej i monitorowania doświadczeń płynących z przywiązania. Jak już wspomniano, doświadczenia w kontaktach z głównym opiekunem mogą wpływać na zawartość umysłu dziecka, ale również na zdolność opracowania tych treści. Ponieważ zdolność do mentalizacji staje się mechanizmem, dzięki któremu relacja opiekun-dziecko wywiera wpływ na tworzenie bezpiecznego przywiązania u dziecka, jednocześnie wpływa na jego rozwój społeczno-poznawczy. Można zatem stwierdzić, że odgrywa główną rolę w procesie przekazywania bezpiecznego przywiązania z opiekuna na dziecko. Rozwój bezpiecznej więzi u dziecka jest wspierany dzięki prawidłowemu mentalizowaniu przez rodzica. Mentalizujący rodzic stymuluje z kolei rozwój zdolności mentalizowania u dziecka. W rezultacie prawidłowo mentalizujące dziecko jest w stanie stworzyć bezpieczne przy- wiązanie do opiekuna (Sharp, Fonagy, 2008). Dzieci, które doświadczyły traumy, rzadziej odnoszą się do własnych stanów mentalnych, mają trudności w odczuwaniu i okazywaniu empatii, gorzej różnicują stany emocjonalne i osiaggają niższe wyniki wyniki w zadaniach badających teorię umysłu (Marszał, 2015), co wskazuje na zaburzenia na różnych płaszczyznach mentalizacji. Fonagy (1994) uważa z kolei, że międzypokoleniowa transmisja przywiązania następuje wraz $\mathrm{z}$ tworzeniem się reprezentacji psychicznych własnych oraz opiekuna. Bierze w tym udział mechanizm funkcjonowania refleksyjnego, który umożliwia dziecku odzwierciedlanie jego stanów emocjonalnych przez matkę oraz przetwarzanie i opracowywanie jego trudnych emocji. Dzięki autorefleksyjności opiekuna jego traumatyczne doświadczenia $\mathrm{z}$ dzieciństwa nie muszą determinować trudności w przywiązaniu w następnych pokoleniach. Rozumienie zachowań dziecka jako stanów mentalnych sprzyja powstawaniu bezpiecznej więzi oraz rozwojowi umiejętności mentalizowania. Jeśli natomiast główny opiekun cechuje się pozabezpiecznym stylem więzi oraz wykazuje niską zdolność do mentalizacji w stosunku do własnego dziecka, wiąże się to z nietypowymi zachowaniami macierzyńskimi. Trudności w dostrzeganiu stanów umysłu dziecka, a w konsekwencji nieprawidłowe odzwierciedlanie, sprzyjają tworzeniu jednego z pozabezpiecznych stylów przywiązania.

Liczne badania wykazały, że opiekunowie, którzy sami doświadczali w dzieciństwie traumatycznych przeżyć, mają deficyty w zakresie budowania więzi i uważności na dziecko, a przeżyta trauma uaktualnia się ponownie w relacji rodzicielskiej. Matki, które w dzieciństwie doświadczały przemocy fizycznej, są bardziej wrogie w relacjach z własnymi dziećmi, a te, które były wykorzystywane seksualnie, są wycofane w kontaktach i wykazują niewielkie zaangażowanie w stosunku do dziecka. Badania pokazują również, że lęk u opiekunów jest silnym predyktorem trudności emocjonalnych, poznawczych i behawioralnych u niemowląt (Behrendt i in., 2019). Wyższy poziom lęku u rodziców wiąże się z uboższymi relacjami współrodzicielskimi, co z kolei jest powiązane 
z bardziej bojaźliwym temperamentem u dziecka (Metz i in., 2018). Udowodniono również związek między dezorganizacją przywiązania niemowlęcia a traumą opiekuna odzwierciedloną w niekonsekwentnym, przestraszonym lub jawnie zagrażającym zachowaniu względem dziecka (Liotti, Farina, 2016). Podsumowując, relacje przywiązania w pierwszych latach życia ulegają dezorganizacji w wyniku interakcji z bezbronnym, przestraszonym opiekunem (Granqvist $i$ in., 2017). Potwierdza to hipotezę, że stan psychiczny rodzica, w którym pośredniczy jego lęk, wycofanie $z$ roli opiekuna lub zagrażające zachowania, dezorganizuje wzorzec przywiązania dziecka.

Badania nad mentalizacją wykazały z kolei, że mentalizacja rodzicielska wspiera zdrowy rozwój społeczno-emocjonalny i społeczno-poznawczy dziecka oraz bezpieczne przywiązanie. Wpływa także na mniejszą liczbę zachowań internalizujących i eksternalizujących wśród przedszkolaków (Dollberg i in., 2020). Mentalizacja rodzicielska pomaga matkom rozumieć ich własne negatywne emocje, takie jak lęk, złość czy strach, oraz odróżniać je od emocji dziecka, a w konsekwencji modulować własne negatywne i nieresponsywne reakcje (Ensink i in., 2016). Badania pokazują również, że osłabiona mentalizacja jest głównym czynnikiem w przebiegu rozwoju psychopatologii, szczególnie w zaburzeniach lękowych wyższy poziom poczucia lęku u rodziców był związany z większą liczbą problemów behawioralnych u dzieci, szczególnie z ich zachowaniami eksternalizacyjnymi. Prawidłowość ta dotyczy zarówno matek, jak i ojców (Dollberg $\mathrm{i}$ in., 2020). Oznacza to, że mentalizacja rodzicielska pełni funkcję ochronną rozwoju dzieci w niekorzystnych warunkach (Bateman, Fonagy, 2019; Lavoie i in., 2014). Deficyty w zakresie mentalizowania mogą zaś utrudniać mentalne powstrzymywanie destrukcyjnych doświadczeń emocjonalnych oraz próby kontrolowania ich ekspresji behawioralnej (Bouchard i in., 2008). Podobnie jest w przypadku mentalizacji rodzicielskiej: opiekunowie podatni na lęk są nadmiernie zaangażowani w emocjonalny świat dziecka i mogą obciążać je własnymi troskami i lękami (Asen, Fonagy, 2012).

\section{PODSUMOWANIE}

Obecnie badacze uznają wpływ wczesnodziecięcych doświadczeń na rozwój psychopatologii oraz różnorakich trudności w dorosłym życiu za oczywisty. Trauma rozwojowa wpływa na wystąpienie prawie wszystkich zaburzeń psychiatrycznych (Farina i in., 2019). Naukowcy w dalszym ciągu poszukują jednak zmiennych pośredniczących między przywiązaniem a psychopatologią. Badania pokazują także, iż większość dzieci doświadczających urazów interpersonalnych nie wykazuje zaburzeń w wieku dorosłym. Chociaż liczne analizy potwierdzają, że wzorzec przywiązania rodzica jest predyktorem tworzenia więzi z dzieckiem (Fearon, Roisman, 2017), to w dalszym ciagu nie są znane mechanizmy działania tej transmisji. Istotne wydaje się wyjaśnienie, dlaczego u osób z tym samym stylem więzi rozwijają się zupełnie różne zaburzenia lub nie występują one wcale, ale doniesienia w literaturze na temat przywiązania i mentalizacji różnią się w zależności od metody pomiaru. Mentalizacja, regulacja emocji i przywiązanie są konstruktami wielowymiarowymi, trudnymi do uchwycenia. Różne metody mierzą ich różne aspekty, dlatego wyniki nie są jednoznaczne i zależą od operacjonalizacji (Marszał, Jańczak, 2017). Ponadto jednym z głównych ograniczeń wskazywanym w literaturze przedmiotu okazuje się brak badań eksperymentalnych (Fearon, Roisman, 2017).

Mając na uwadze, że mentalizacja jest czynnikiem ochronnym w kontekście traumy oraz że odgrywa istotną rolę w pojawieniu się lub zaostrzeniu zaburzeń psychotycznych, a także pośredniczy w związku między traumą dziecięca a objawami negatywnymi u pacjentów psychotycznych (Weijers i in., 2020), można wnioskować, iż jest zmienną pośredniczącą pomiędzy wczesnodziecięcymi doświadczeniami a rozwojem zaburzeń. $Z$ analizy literatury wynika, że przywiązanie transmitowane jest międzypokoleniowo także za pomocą mechanizmu mentalizacji. Proces, dzięki któremu rozwijanie bezpiecznej więzi u dziecka jest wspierane przez dokładne i właściwe mentalizowanie przez opiekunów, również może być dwukierunkowy (Sharp, Fonagy, 2008). Umiejętność mentali- 
zowania tworzy się w pierwszych latach życia dziecka i w większym stopniu zależy od oddziaływań środowiskowych niż od predyspozycji genetycznych, co oznacza, że istotny wpływ na jej rozwój ma relacja z figurą przywiązania (Fonagy i in., 2008). Powstaje między innymi dzięki rozumieniu świata wewnętrznego dziecka oraz trafności odzwierciedlania subiektywnego doświadczenia dziecka przez głównego opiekuna. Według Dollberg i in. (2020) możliwym wyjaśnieniem związku mentalizacji rodzicielskiej z bezpiecznym przywiązaniem jest to, że prawidłowo mentalizujący rodzic pokazuje dzieciom strategie wyrażania emocji. Pomaga w ten sposób zrozumieć, jak stany psychiczne i zachowania są ze sobą powiązane, co powoduje zwiększenie zdolności samoregulacji u dzieci. Obecnie teoria mentalizacji stanowi uznany sposób konceptualizacji zaburzeń psychicznych u dorosłych, ze szczególnym uwzględnieniem zaburzeń osobowości, w których występują trudności w regulacji emocji (Marszał, 2015).

W zdecydowanej większości mentalizowanie dotyczy teraźniejszości, czyli stanów bieżących umysłu, ale z uwagi na to, że jest konstruktem osadzonym w czasie, z perspektywy psychoterapii zrozumienie dawnych stanów umysłu ma ogromne znaczenie (Allen $\mathrm{i}$ in., 2014). Kiedy trauma wiąże się $\mathrm{z}$ niepowodzeniem w mentalizacji, odzwierciedlenie bezpiecznego przywiązania pomaga złagodzić i regulować emocje, niekiedy przytłaczające. Psychoterapia to forma relacji przywiązaniowej, której głównym celem jest zapewnienie pacjentowi bezpiecznych warunków do reorganizacji natrętnych wspomnień, nadania sensu utraty więzi oraz odbudowy bezpiecznej bazy (Allen, 2013). Wczesne traumatyczne doświadczenia $\mathrm{w}$ relacji z pierwszym opiekunem mogą tworzyć negatywne i fragmentaryczne obrazy siebie i innych, jednocześnie generujące poczucie bezsilności i nieufności wobec ludzi. To z kolei może utrudniać budowanie przymierza terapeutycznego, niezbędnego do powodzenia każdej formy terapii (Farina, Liotti, 2013). Praca terapeutyczna opiera się w dużej mierze na zachęcaniu pacjenta do mentalizowania na poziomie jawnym. Ma to przede wszystkim charakter narracyjny. Zaburzenia więzi i trauma wczesnodziecięca prowadzą do upośledzenia rozwoju zdolności narracyjnej, co z kolei znajduje odzwierciedlenie w mentalizacji jawnej. Usztywniona narracja i trudności w narracyjnym ujęciu urazu utrudniają zdrowienie z następstw traumatycznych doświadczeń (Allen i in., 2014). Chociaż większość form psychoterapii (terapia poznawcza, trening uważności, terapia skoncentrowana na pacjencie i terapia behawioralna) polega na wzmacnianiu procesu mentalizacji, to tylko niektóre podejścia, takie jak terapia oparta na mentalizacji (MBT) i pewne formy terapii psychodynamicznej, badają lub mierzą rozwój zdolności do mentalizacji oraz korelują je z redukcją objawów, z jakimi zgłaszają się pacjenci (Oehlman i in., 2020).

W przypadku traumy rozwojowej, w związku ze złożonością objawów, obraz kliniczny zaburzenia jest skomplikowany, co utrudnia postawienie diagnozy oraz pogarsza rokowania terapeutyczne. Coraz większa liczba badań pokazuje, że historia skumulowanych urazów z dzieciństwa generuje trudności w leczeniu, które wymagają specjalistycznej wiedzy i szkoleń dla terapeutów (Farina i in., 2019). Znajomość neurologicznych skutków wczesnych traumatycznych doświadczeń nie tylko jest istotna dla zrozumienia psychopatologii dysocjacyjnej, ale także może pomóc terapeucie w opracowaniu strategii terapeutycznej. Zmiana struktur mózgu na skutek doświadczania traumy w dzieciństwie niesie zagrożenie dla oddziaływań terapeutycznych i farmakologicznych. Terapeuta może być zniechęcony brakiem natychmiastowej pozytywnej odpowiedzi na działania terapeutyczne. Szczególną trudność stanowić charakterystyczny dla traumatycznych wczesnodziecięcych doświadczeń deficyt regulacji emocji u pacjenta. Współczesna wiedza neurobiologiczna daje podstawy do twierdzenia, że oddziaływania terapeutyczne powodują wzrost plastyczności neurobiologicznej i zmiany morfofunkcjonalne mózgu, nie tylko w okresie dziecięcym, ale także w dorosłości. Taka wiedza pozwala terapeucie przewidzieć prawdopodobieństwo stopniowego zmniejszania trudności pacjenta (Liotti, Farina, 2016).

Z literatury przedmiotu wynika, że podejmując prewencyjne działania u rodziców, których 
historia wskazuje na traumatyczne doświadczenia, trudności w regulacji emocji i mentalizowaniu, można przerwać międzypokoleniową transmisję pozabezpiecznego wzorca więzi. Psychoedukacja dostępna w postaci zajęć wykładowych czy warsztatowych mogłaby stymulować rozwój ufnej więzi i zwiększyć świadomość rodzicielską w zakresie relacji rodzic-dziecko oraz jej wpływu na rozwój społeczno-emocjonalny dziecka. Ponieważ mentalizacja oddziałuje na proces regulacji emocji przez obniżenie napięcia i przepracowywanie doświadczeń emocjonalnych, wydaje się, że poszerzanie wiedzy i samoświadomości z zakresu procesów mentalizowania u nastolatków mogłoby zaowocować pogłębieniem zdolności do opracowywania negatywnych doświadczeń. Warto rozważyć istotność psychoedukacji w zakresie mentalizowania dla zdrowia psychicznego dzieci, młodzieży i dorosłych.

\section{BIBLIOGRAFIA}

Adamczyk L. (2013), Mentalizacja. Cz. 1: Wprowadzenie do zagadnienia, wymiary mentalizacji. Psychoterapia, 3(166), 25-36.

Ainsworth M.D., Blehar M.C., Waters E., Wall S. (1978), Patterns of Attachment: Assessed in the Strange Situation and at Home. Hilsdale, NJ: Lawrence Erlbaum.

Allen J.G. (2013), Mentalizing in the Development and Treatment of Attachment Trauma. London: Karnac.

Allen J.G., Fonagy P., Bateman A. (2014), Mentalizowanie w praktyce klinicznej. Tłum. M. Cierpisz. Kraków: Wydawnictwo Uniwersytetu Jagiellońskiego.

Asen E., Fonagy P. (2012), Mentalization-based therapeutic interventions for families. Journal of Family Therapy, 34(4), 347-370.

Bateman A., Fonagy P. (2019), A randomized controlled trial of a mentalization-based intervention (MBTFACTS) for families of people with borderline personality disorder. Personality Disorders: Theory, Research, and Treatment, 10(1), 70-79.

Behrendt H.F., Wade M., Bayet L., Nelson C.A., Bosquet Enlow M. (2019), Pathways to social-emotional functioning in the preschool period: The role of child temperament and maternal anxiety in boys and girls. Development and Psychopathology, 26, 1-14.

Bouchard M.A., Target M., Lecours S., Fonagy P., Tremblay L.M., Schachter A., Stein H. (2008), Mentalization in adult attachment narratives: Reflective functioning, mental states, and affect elaboration compared. Psychoanalytic Psychology, 25(1), 47-66.

Bowlby J. (1973), Attachment and Loss. Separation: Anxiety and Anger. New York: Basic Books.

Bowlby J. (1988), A Secure Base: Parent-Child Attachment and Healthy Human Development. New York: Basic Books.

Daniel S. (2009), The developmental roots of narrative expression in therapy: Contributions form attachment theory and research. Psychotherapy Theory, Research, Practice, Training, 46(3), 301-316.

De Bellis M.D., Zisk A. (2014), The biological effects of childhood trauma. Child and Adolescent Psychiatric Clinics of North America, 23(2), 185-222.

Dollberg D., Hanetz Gamliel K., Levy S. (2020), Mediating and moderating links between coparenting, parental mentalization, parents' anxiety, and children's behavior problems. Journal of Family Psychology. Advance online publication.

Ein-Dor T., Doron G., Solomon Z., Mikulincer M., Shaver P.R. (2010), Together in pain: Attachmentrelated dyadic processes and posttraumatic stress disorder. Journal of Counseling Psychology, 57, $317-327$

Ein-Dor T., Viglin D., Doron G. (2016), Extending the transdiagnostic model of attachment and psychopathology. Frontiers in Psychology, 7, Article 484.

Ensink K., Normandin L., Plamondon A., Berthelot N., Fonagy P. (2016), Intergenerational pathways from reflective functioning to infant attachment through parenting. Canadian Journal of Behavioural Science / Revue canadienne des sciences du comportement, 48(1), 9-18. 
Farina B., Liotti G. (2013), Does a dissociative psychopathological dimension exist? A review on dissociative processes and symptoms in developmental trauma spectrum disorders. Clinical Neuropsychiatry, 10(1), 11-18.

Farina B., Liotti M., Imperatori C. (2019), The role of attachment trauma and disintegrative pathogenic processes in the traumatic-dissociative dimension. Frontiers in Psychology, 10.

Fearon R.M.P., Roisman G.I. (2017), Attachment theory: Progress and future directions. Current Opinion in Psychology, 15, 131-136.

Fonagy P. (1994), Mental representations from an intergenerational cognitive science perspective. Infant Mental Health Journal, 15(1), 57-68.

Fonagy P., Gergely G., Target M. (2008), Psychoanalytic constructs and attachment theory and research. W: J. Cassidy, P.R. Shaver (eds.), Handbook of Attachment: Theory, Research, and Clinical Applications, 783-810. New York: The Guilford Press.

Fonagy P., Luyten P. (2009), A developmental, mentalization-based approach to the understanding and treatment of borderline personality disorder. Development and Psychopathology, 21(4), 1355-1381.

Fricker J., Moore S. (2002), Relationship satisfaction: The role of love styles and attachment styles. Current Research in Social Psychology, 7(11), 182-204.

Granqvist P., Sroufe L.A., Dozier M., Hesse E., Steele M., Ijzendoorn M. van i in. (2017), Disorganized attachment in infancy: A review of the phenomenon and its implications for clinicians and policy-makers. Attachment and Human Development, 19, 534-558.

Groh A.M., Fearon R.M.P., IJzendoorn M.H. van, Bakermans-Kranenburg M. J., Roisman G.I. (2016), Attachment in the early life course: Meta-analytic evidence for its role in socioemotional development. Child Development Perspectives, 11(1), 70-76.

Hertsgaard L., Gunnar M., Erickson M., Nachmias M. (1995), Adrenocortical responses to the strange situation in infants with disorganized/disoriented attachment relationships. Child Development, 66(4), 1100-1106.

Illing V., Tasca G.A., Balfour L., Bissada H. (2010), Attachment insecurity predict seating disorder symptoms and treatment outcomes in a clinical sample of women. Journal of Nervous and Mental Disease, 198, 653-659.

Iniewicz G. (2008), Zaburzenia emocjonalne u dzieci i młodzieży z perspektywy teorii przywiązania. Psychiatria Polska, 27(5), 671-682.

Kim E.J., Pellman B., Kim J.J. (2015), Stress effects on the hippocampus: A critical review. Learning and Memory, 22(9), 411-416.

Kolk B.A. van der, McFarlane A.C., Weisaeth L. (eds.) (1996), Traumatic Stress: The Effects of Overwhelming Experience on Mind, Body and Society. New York: Guilford Press.

Krueger R.F., Markon K.E. (2011), A dimensional-spectrum model of psychopathology: Progress and opportunities. Archives of General Psychiatry, 68(1), 10-11.

La Guardia J.G., Ryan R.M., Couchman C.E., Deci E.L. (2000), Within-person variation in security of attachment: A Self-determination theory perspective on attachment, need fulfillment, and well-being. Journal of Personality and Social Psychology, 79, 367-384.

Lavoie M., Battaglia M., Achim A. (2014), A meta-analysis and scoping review of social cognition performance in social phobia, posttraumatic stress disorder and other anxiety disorders. Journal of Anxiety Disorders, 28(2), 169-177.

Lindgren L., Bergdahl J., Nyberg L. (2016), Longitudinal evidence for smaller hippocampus volume as a vulnerability factor for perceived stress. Cerebral Cortex, 26(8), 3527-3533.

Liotti G., Farina B. (2016), Traumatyczny rozwój. Etiologia, klinika i terapia wymiaru dysocjacyjnego. Tłum. H. Michalska, Bledzew: Fundacja Przyjaciele Martynki.

Madigan S., Atkinson L., Laurin K., Benoit D. (2013), Attachment and internalizing behavior in early childhood: A meta-analysis. Developmental Psychology, 49(4), 672-689.

Marszał M. (2015), Mentalizacja w kontekście przywiqzania. Zdolność do rozumienia siebie i innych u osób z osobowościq borderline. Warszawa: Delfin.

Marszał M., Jańczak A. (2017), Emotion dysregulation, mentalization and romantic attachment in the nonclinical adolescent female sample. Current Psychology, 37(4), 894-904.

Meins E., Fernyhough C., Fradley E., Tuckey M. (2001), Rethinking maternal sensitivity: Mothers' comments on infants' mental processes predict security of attachment at 12 months. Journal of Child Psychology and Psychiatry, 42(5), 637-648. 
Metz M., Majdandžić M., Bögels S. (2018), Concurrent and predictive associations between infants' and toddlers' fearful temperament, coparenting, and parental anxiety disorders. Journal of Clinical Child and Adolescent Psychology, 47(4), 569-580.

Migda M. (2015), Trauma więzi a psychoterapia pacjentów z diagnozą PTSD w oparciu o mentalizację. Psychoterapia, 3, 99-105.

Mikulincer M., Florian V. (2003), Attachment style and affect regulation: Implications for coping with stress and mental health. W: G.J.O. Fletcher, M.S. Clark (eds.), Blackwell Handbook of Social Psychology: Interpersonal Processes, 535-557.

Mikulincer M., Shaver P.R. (2007), Attachment in Adulthood: Structure, Dynamics, and Change. New York: Guilford.

Oehlman Forbes D., Lee M., Lakeman R. (2020), The role of mentalization in child psychotherapy, interpersonal trauma, and recovery: A scoping review. Psychotherapy. Advance online publication.

Schore A.N. (2001), The effects of early relational trauma on right brain development, affect regulation, and infant mental health. Infant Mental Health Journal, 22(1-2), 201-269.

Senator D. (2010), Więź w rodzinie a ryzyko zaburzeń rozwoju emocjonalnego dzieci i młodzieży. W: B. Tryjarska (red.), Bliskość w rodzinie. Więzi w dzieciństwie a zaburzenia $w$ dorostości, 43-61. Warszawa: Wydawnictwo Naukowe Scholar.

Sharp C., Fonagy P. (2008), The parent's capacity to treat the child as a psychological agent: Constructs, measures and implications for developmental psychopathology. Social Development, 17, 737-754.

Slade A., Grienenberger J., Bernbach E., Levy D., Locker A. (2005), Maternal reflective functioning, attachment, and the transmission gap: A preliminary study. Attachment and Human Development, 7(3), 283-298.

Słaboń-Duda A. (2011), Wczesna relacja matka-dziecko i jej wpływ na dalszy rozwój emocjonalny dziecka. Psychoterapia, 2(157), 11-18.

Teicher M., Samson J., Anderson C., Ohashi K. (2016), The effects of childhood maltreatment on brain structure, function and connectivity. Nature Reviews: Neuroscience, 17, 652-666.

Turner, J. M., Wittkowski, A., \& Hare, D. J. (2008). The relationship of maternal mentalization and executive functioning to maternal recognition of infant cues and bonding. British Journal of Psychology, 99(4), 499-512. https://doi:10.1348/000712608x289971

Wei M., Mallinckrodt B., Russell D.W., Abraham W.T. (2004), Maladaptive perfectionism as a mediator and moderator between adult attachment and depressive mood. Journal of Counseling Psychology, 51(2), 201-212.

Weijers J.G., Kate C., Debbané M., Bateman A.W., Jong S. de, Selten J.P., Eurelings-Bontekoe E.H.M. (2020), Mentalization and psychosis: A rationale for the use of mentalization theory to understand and treat nonaffective psychotic disorder. Journal of Contemporary Psychotherapy, 50(3), 223-232. 